Luiza Noli Silveira

\title{
WHY ARE MY TEENAGE STUDENTS MORE ACCURATE IN ENGLISH SPEAKING THAN IN WRITING?
}

DEPARTAMENTO DE LETRAS

Curso de Espacialização em Língua Inglesa

Rio de Janeiro

Julho de 2020 


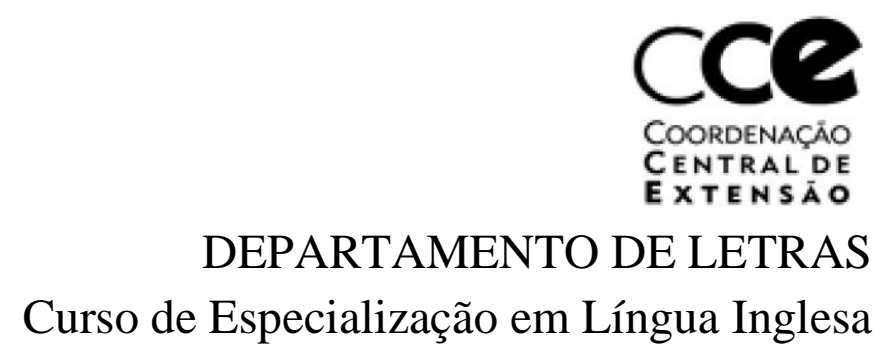

\section{WHY ARE MY TEENAGE STUDENTS MORE ACCURATE} IN ENGLISH SPEAKING THAN IN WRITING?

Luiza Noli Silveira

Prof ${ }^{a}$ Sabine Mendes Moura Departamento de Letras - PUC-Rio

Orientadora

Rio de Janeiro

Julho de 2020 


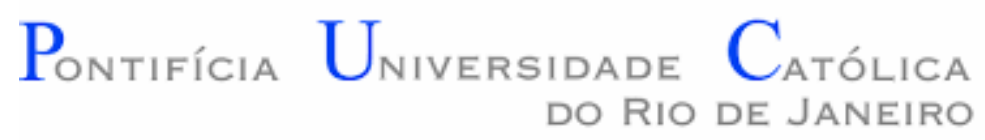

Luiza Noli Silveira

\section{WHY ARE MY TEENAGE STUDENTS MORE ACCURATE IN ENGLISH SPEAKING THAN IN WRITING?}

Monografia apresentada ao programa de Pós-graduação em Letras da PUCRio como requisito parcial para obtenção do título de especialista em Língua Inglesa.

Prof ${ }^{\text {a }}$ Sabine Mendes Moura Departamento de Letras - PUC-Rio

Orientadora

Rio de Janeiro

Julho de 2020 


\section{ACKNOWLEDGEMENTS}

Firstly, I would like to thank my parents and my grandmother for always supporting me in my choices and dreams as a professional.

To my brother and best friend, I thank you for the relaxing and humorous moments during any moment of hard work.

I would also like to express my gratitude to all the professors at PUC-Rio, especially my advisor, Sabine Mendes, whose intelligence, perseverance and kindness have helped me pave the way towards what I call success.

And, finally, to my beloved grandfather (in memoriam), wherever perfect you are, I can feel your pride and support, as always. 


\begin{abstract}
Silveira, Luiza Noli; Moura, Sabine. Why are my teenage students more accurate in English speaking than in writing? Rio de Janeiro, 2020, 42, p. Monograph - Departamento de Letras, Pontifícia Universidade Católica do Rio de Janeiro.
\end{abstract}

When coming across with a challenge in a new language, it is quite common to find some skills easier to learn than others. The purpose of this study is to make myself and other teachers aware of our youngsters' difficulties and how we can make them understand and, therefore, exploit their own obstacles. In this paper, I analyzed a class of mine of four students, and, through Exploratory Practice and the concept of Language Ecology, I have tried to understand the reason why they make more written mistakes than speaking ones. The chosen methodology is one in which we integrated reflection into our activities so as to enhance our understanding about the issue during our class time. Most of them preferred to engage in speaking activities during classes and found, as well, to be more enjoyable and less difficult to speak English and listen to the language outside of the classroom context. Analysis suggests that these young learners relate far more to sounds than to written words.

KEY WORDS: English teaching; Language learning; Exploratory Practice; Language Ecology; Communicative skills 


\section{RESUMO}

Silveira, Luiza Noli; Moura, Sabine. Por que meus alunos adolescents cometem menos erros ao falar inglês do que ao escrever? Rio de Janeiro, 2020, 42, p. Monograph - Departamento de Letras, Pontifícia Universidade Católica do Rio de Janeiro.

Ao se deparar com um desafio em um novo idioma, é bastante comum achar algumas habilidades mais fáceis de aprender do que outras. $\mathrm{O}$ objetivo deste estudo é me conscientizar, assim como outros professores, das dificuldades de nossos alunos e como podemos fazê-los compreender e, portanto, explorar seus próprios obstáculos. Neste artigo, analisei uma turma minha de quatro alunos e, através da Prática Exploratória e do conceito de Ecologia da Linguagem, tentei entender por que é mais comum eles cometerem erros na escrita do que na fala. A metodologia aplicada é com o propósito de integrarmos a reflexão em nossas atividades de forma a ampliar nosso entendimento sobre o tema durante o tempo de aula. A maioria deles preferiu se engajar em atividades de conversação durante as aulas e descobriu, também, ser mais agradável e menos difícil falar inglês e ouvir o idioma fora do contexto da sala de aula. A análise sugere que esses jovens aprendizes se relacionam mais facilmente com sons do que com palavras escritas.

PALAVRAS-CHAVES: Ensino da língua inglesa; Aprendizado de língua; Prática Exploratória; Ecologia da linguagem; habilidades comunicativas 


\section{TABLE OF CONTENTS}

1. INTRODUCTION.................................................. 5

2. LITERATURE REVIEW ........................................... 8

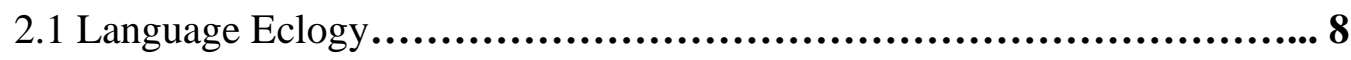

2.2 Exploratory Practice................................................... 11

3. METHODOLOGY ........................................................ 15

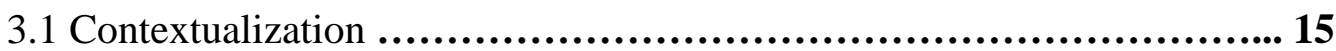

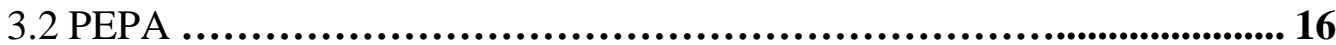

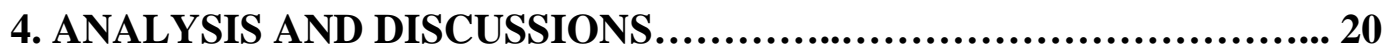

5. FINAL CONSIDERATIONS ................................................ 31

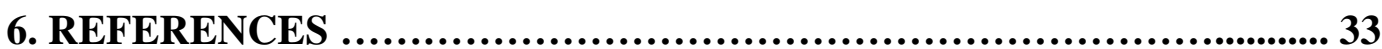

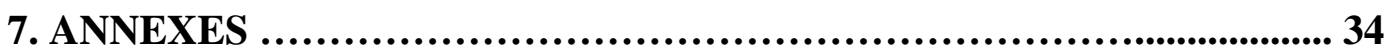

TABLES

TABLE 1 (Notes about the students' personalities) $\ldots . \ldots \ldots \ldots \ldots \ldots . . \ldots \ldots \ldots$

TABLE 2 (Students' answers to the questionnaire) $\ldots \ldots \ldots \ldots \ldots \ldots \ldots \ldots \ldots . \ldots 20$ 


\section{INTRODUCTION}

A research project may begin in a 'telling moment' in the language classroom (KRAMSCH, 2002, p.196). I would have to say that, as a student, I had difficulties, at first, to grasp this concept, however, as a teacher, I naturally welcomed the feeling of such a moment.

As a student at the English Post-Graduate Level at PUC-Rio, I was previously concerned with the idea of coming up with a question with logical and correct answers followed by a straight $\mathrm{A}$ and a sensation of relief. But, after acknowledging that we, as tutors, should attempt to understand our own puzzles rather than solve them and that our "answers" were acceptable and debatable hypotheses (ALLWRIGHT, 2003), it finally dawned on me that my question would instinctively come to my mind and it would be perfectly reasonable not to figure it out, but rather discuss it.

Since I spend many hours of my working weekdays around the English language, I decided that I would work with my daily professional experience. I teach at a private English school for kids and teenagers and, for a while, I taught private lessons for adults as well. Up until the beginning of last year, all my students were either children who were then starting to read and write in their mother tongue or adult beginners who had decided to devote their time to study a second language for career purposes. I realized that I was not speaking English nearly as much as I would like during classes, since this world of being fluent in a new language was far from familiar to them and I felt less challenged. But, when the first semester started, I was assigned to a new challenge: a class of four teenage boys, all around the same age and from different schools and backgrounds. On our first day, I was astonished to find out how they could comprehend everything. Our exchange of words and ideas was one hundred percent in English, regardless of the content or the seriousness of the subject. Needless to say, I was amazed. Their ease reminded me of my teenage years and how I was, as well, already making jokes or succeeding on being sarcastic in another language. Besides nostalgic, it felt both natural and intriguing.

After a few classes and assignments, I, as an English teacher, noticed that, regarding speaking and listening, they were succeeding in most activities. I could 
honestly say that I rarely interrupted them to correct any mispronounced word. However, I could notice more lapses in their writing. Curiosity stroke and, just like Kramsch had convinced me, it was natural, and I had my research question. Why are my teenage students more accurate in English speaking than writing?

Lincoln and Guba wrote that "the participatory paradigm principle is based on the congruence of experiential, presentational, propositional and practical knowing leading to action to transform the world in the service of human flourishing" (2010, p.170). Considering this definition, I believe that conducting research through the participatory paradigm would provide me more space for thinking and discussion since I determined interaction happening among all the participants. Therefore, I think that such a paradigm has much to offer to the participatory researcher as to the other participants.

I aim at conducting this research through Exploratory Practice (EP) which focuses on understanding rather than solving a problem in the classroom. At first, I will monitor my classes to better perceive the circumstances. Secondly, my students and I will participate in an activity in order to get closer to their realities concerning the language skills inside and outside our learning environment and, at last, I will propose activities in order for all of us, together, to understand and encourage ourselves to be more self-critical in our learning process.

As a practitioner researcher, my purpose is to discuss why my teenage students make fewer mistakes while speaking rather while writing. From the authors I have read as a post-graduation student, the constructivist Leo Van Lier was able to equip me with an analytical tool based on his theory on Language Ecology which contributes with an idea of language learning as an interconnectivity between perception and action and how your life can genuinely offer you different tools, whether you are aware of it or not (2008, p. 598). Besides Leo Van Lier, I will further write about the concept of EP, which is a form of 'inclusive practitioner research where teachers and learners are co-practitioners, and where learners investigate their own puzzles about their own learning lives' $(2009$, p. 5).

During my three-year experience as a teacher, I had never stopped to think that we were constantly asking ourselves questions that puzzled us for days. Now 
the moment has come to investigate one of those so called 'telling moments' I did not know I was so restless to write about. 


\section{LITERATURE REVIEW}

\subsection{Language Ecology}

When studying Biology at school, students stumble upon the quite common term of Ecology. Its Greek origin explains the etymology of the word Ecology as nothing more than the study of the environment. Ancient Greek philosophers, like Hippocrates and Aristotle, were the pioneers of natural history records; however, they had a view of species as static (EGERTON, 2001, p.94).

Life may be conceived as a special process of movement (HAECKEL, 1905, p.28). As German biologist Enrst Haeckel published over a century ago, modern researchers have realized that every living species submits to change. This branch of science has proven there is no such thing as an immutable being in a changeless environment. Ecology is the total science of the organism's relations to the surrounding environment, to which we can count in a wider sense all 'conditions of existence" (HAECKEL, 1866, in VAN LIER, 2008).

In ecology, environment refers to the natural world where people, animals and plants live, as well as the conditions that affect the behavior and evolution of somebody or something. It is comprehensible that the environment is the physical space where living and non-living creatures are acting and reacting with each other and with the environment itself. Therefore, a forest, a savanna or a botanic garden are some environments, as well as a country, a household, a neighborhood, a school or even a classroom. The difference is who the beings are and how they relate within the environment and with its growth- purpose properties however, in all these so called "ecosystems", there is life and, therefore, action, interaction and reaction.

We have grown accustomed to believing that ecology is strictly linked to biology. It is worth emphasizing that ecology can, in principle, apply to any field of study that deals with "organisms" whose relationships and interactions with one another are important, and this includes all human and social sciences (HAECKEL, In VAN LIER, 2008, p.596). Many of such social sciences are language related and, within the field of Educational Linguistics (EL), there is the subcategory of Language Ecology, which is the study of interactions between any given language and its environment (HAUGEN, 2001, in KRAMSCH, 2007). 
This relatively recent term of Language Ecology only came to surface in 1972 through the Norwegian linguist Einar Haugen, whose research in Educational Linguistics was linked with the study of German biologist Enrst Haeckel. In Language Ecology, the scope of an organism includes human beings and their surrounding spaces. Furthermore, the environment, somehow, provides any language insight for human development.

The constructivist author Leo Van Lier believed that:

an ecological perspective on language learning sees language as part of larger meaning-making resources that include the body, cultural-historical artifacts, the physical surroundings, in short, all the affordances that the physical, social, and symbolic worlds have to offer (VAN LIER, 2008, p.599).

In this paper, I am going to focus on understanding how a group of students of mine have acquired English Language knowledge considering the relationship between their experienced acquisition of knowledge and the diverse human ambiences where they have expressed it linguistically.

I have mentioned in the Introduction that, after some reflective teaching, I had come to realize that a specific group of students of mine were making more mistakes during their English writing assignments but less while speaking the language. As a researcher, I will attempt to understand what properties are presented in their lives outside of our own teaching- learning space that, consequently, causes them to be more precise while expressing themselves through sounds. As Van Lier would confirm in his studies, the language classroom is not an island unto itself (2008, p. 600). It would be very conceited of my part to underestimate my students' capacity for self-teaching, even in moments which they are not cognizant of an ongoing learning process.

My students' common environment is our classroom, and, inside its four walls, there are many components that normally benefit their practice, such as the books, the whiteboard, the activities, their relationships, the computer, me and among others. Yet, besides their one-hour class, there are other environments in which they are submitted to new language material. The concept of Language Ecology embraces not only the context of classroom learning but, more fundamentally, the very definitions of language, of development, and of mind 
(VAN LIER, 1997, p.783). Through the course of my research, it is my objective to make me and my students question or, if even possible, identify the agents accountable for their bigger ease at speaking.

Leo Van Lier believes that language does not act alone in the meaningmaking process and that it can occur by purpose or accident, in settings that are oriented toward language education (2008, p.600). I inquire myself whether my students are aware of how their settings can provide tools towards second language acquisition. Accidental or not, their non-classroom environments are regularly also granting material in English, especially in our 21st century, due to the media being majorly restrained by Western culture. Kress (2000, p.14) affirms that over the last two or three decades a revolution has taken place in the area of communication.

Due to his ecological perspective on learning, Van Lier also considered the role of technology as an English-enhancing attribute bestowed by the environment. In his work All hooked up: an ecological look at computers in the classroom, the author mentions that technology has much to offer, if we put it into the service of a sound pedagogy (VAN LIER, 2003, p.282). Somehow, during the eras we have been currently living, technology has had a great impact in young learners everywhere around the world and it is compelling to recognize them as major cultural data holders.

The nature of language itself must also be seen to involve not just words and syntax, but also all other sources of meaning making that are available in the environment (VAN LIER, 2008, p.598). After coming across with this passage during my readings, I wonder what my students' sources are in their daily routine and, likewise, how they further contribute to speaking rather than to the skill of writing. There is a connection between perception and action and that is multisensory, involving all senses (KRAMSCH, 2008).

Leo Van Lier regarded Second Language Acquisition as an emergent reality, even if unperceivable by the learning individual:

A semiotic and ecological view of language and of learning entails that the context - physical, social and symbolic - is a central element in teaching and learning, and that issues such as embodiment of language and spatio-temporal structures are 
instrumental in the creation of learning opportunities. (VAN LIER, 2004, p.79).

A teenager can amass extra English language knowledge by traveling to an English-speaking country, by talking to native speakers, by reading a book or simply by standing there and absorbing, even unnoticing, whatever he or she is capable of. I might be expected to participate in a conversation but remain silent, that is also movement (VAN LIER, 2010, p.4).

\subsection{Exploratory Practice}

As a student of the field of Applied Linguistics, I am now familiar, through the help of my professors, with the fact that we, as teachers, bear constant puzzles in our minds. These questions move us toward becoming better educators. I have learned that they naturally come to us once we become professionals and this paper has the intention of maturing one of these discussions into research for debating and, consequently, better teaching. The research process thus becomes the beginning of new processes and plans for the classroom (KRAMSCH, 2002, p.196). So why not start as early as possible?

It has become axiomatic that research into classroom language learning and teaching should be participatory, egalitarian, and empowering (HANKS, 2017, p.1). Over the last decades, researchers have developed different approaches to which a participatory practitioner could engage to conduct research. Teachers can develop strategies for intervention or change, depending on their needs (RICHARDS and LOCKHART, 1996, p.6). After having come to the realization of what my research question would be, my next step was uncovering the most personally suitable approach to advance enlightening on why my teenage students of a specific classroom are more accurate in English speaking than writing.

Language Ecology is about understanding how second language is apprehended by learners in different environments, whether they are aware of it or not. An organism learns and grows so long as it actively engages in and with its environment (VAN LIER, 2008, p.600). Language development happens through interaction and makes way to the teaching-learning process to arise. For that reason, I opted for the approach which takes interaction and integration for debating, understanding and development into consideration. 
Dick Allwright wrote that:

Exploratory Practice is a way of getting teaching and learning done so that the teachers and the learners simultaneously develop their own understandings of what they are doing as learners and teachers. (ALLWRIGHT, 2006, p.15).

While reflecting upon my classroom practice, I have noticed that most of my students were making fewer mistakes while speaking rather than writing. Since the school I work at does not adhere to a specific teaching methodology, it would be of great importance for my students to be aware as well as to be provided time and space for discussion. Language Ecology has offered me different possibilities to explain their current circumstances in second language acquisition (SLA) and, through EP, I would invest in activities that could invite them to come to their own conclusions, unknowingly, through the linguistic concept of ecology. This work is about bringing language awareness through the already existing language awareness.

According to Allwright, EP's main issue is understanding any issue, before thinking about fixing or improving the situation. It is fundamental for the classroom practice to develop through integration among teacher and students towards mutual growth. The first principle of EP is to put quality of life first, to allow the demands of the life of the group to be considered as a leading force, as the most important issue for those involved in the life in the classroom (ALLWRIGHT AND HANKS, 2009, p. 150).

When becoming aware of what EP has been aiming to do, I could not help but notice how it can naturally connect to language teaching-learning as an ecological approach. Words like 'cooperatively', 'developing' and 'integrating', motivated me to adopt the framework of EP to make me and my students understand their own natural process.

$\mathrm{EP}$ is a form of practitioner research in which learners as well as teachers are encouraged to investigate their own learning teaching process, while concurrently practicing the target language (HANKS, 2017, p.2). While writing about Language Ecology, I indicated how distinct environments can broaden a language learner's expertise and as recognized previously, the classroom is one of 
these environments. I expressed about how I wanted my students to be aware of their levels of different language skills that are bagged throughout their daily lives. I started questioning myself why not use one of these environments to discuss about other ones and, therefore, engage into understanding. My intention is to promote interaction to talk about all sorts of other interactions that provided knowledge to my students and, consequently, more knowledge.

In order to truly examine whatever puzzle is in mind, teachers and students rely on investigating tools developed by EP researchers known as Potentially Exploitable Pedagogical Activities (PEPA). "The PEPA was implemented by creating and facilitating a speaking and collaborative activity that aimed to create a whole class discussion" (HANKS, 2018, p.127). As a participatory researcher, I would develop my own PEPA to create and allow space for understanding and discussion with my students. "The PEPA is designed to integrate the work for understanding into existing curricular activity" (ALLWRIGHT, 2003, p.129). As EP was my preferred method to operate my studies, I will illustrate the steps of my PEPA in the second part of the Methodology section of this paper and, afterwards, the analysis and findings of my research question.

We, as language students, have proven to be skillful on developing content. In order to base my studies on the concepts of Language Ecology and EP, I would have to understand how they perceive the learner, since they are of major importance in the development of this study.

Learners are key because they are the only people who can do their own learning and consequently develop. (ALLWRIGHT AND HANKS, 2009). According to Allwright and Hanks, there are five fundamental propositions about learners in EP.

1. Learners are unique individuals who learn and develop best in their own idiosyncratic ways.

2. Learners are social beings who learn and develop best in a mutually supportive environment.

3. Learners are capable of taking learning seriously. 
4. Learners are capable of independent decision-making.

5. Learners are capable of developing as practitioners of learning.

When coming across with these words, I could comprehend better how, for this paper, Language Ecology and EP would complement each other when pursuing my analysis. From an ecological perspective, all communicative acts in a learning environment have multiple reasons, causes, and interpretive potential, depending on all the relationships between and among all the participants in the setting, as well as the environment itself. (VAN LIER, 2008, p.601).

In both conceptual frameworks, the learners' capacity to acquire knowledge by themselves and how they can develop based on the moment they are immersed in alongside its supportive environment. 


\section{METHODOLOGY}

\subsection{Contextualization}

This paper is focused on investigating why a group of students of mine indicated having more difficulties while engaging in writing activities yet basically excelling in English speaking. In order to better comprehend the outcomes of this study, it is of extreme importance to be sensible regarding the circumstantial context within which this research has been unfolded. For that reason, the first part of the Methodology section is to simply help my readers situate themselves in a specific context in which they have not participated.

Since 2018, I have been teaching English in a private English school for children and teenagers in Botafogo, in the city of Rio de Janeiro, Brazil. Unlike traditional English courses, the institution offers different features related to its teaching methodology and spatial setting. The maximum number of students per class is five, for the purpose of granting unlimited treatment to all students, whether it is a very shy one, the opposite or even that child whose concentration needs extra diligence, or any other motive. Secondly, the school does not impose a specific teaching method or material, meaning that the teachers are free to decide how to prepare or plan their classes when preparing a class, as long as they respectfully meet their children`s needs and personalities. Moreover, the teachers can choose whether to use the complete material offered by the school when preparing the classes, if they feel it is more suitable for that specific group of students and moment.

In the introduction of this paper, I mention how most of my classes at the school are of young children who are beginners in English, so it was basically impossible to communicate with them through English constantly. However, I was granted a class of four teenage boys, around the age of fourteen and, from day one, I was utterly impressed by their pronunciation and few grammar errors during our conversations. Throughout the semester, I had noticed that most of their mistakes were related to spelling and they happened more often in the writing tasks. After puzzling for some time of my part, I have decided on my research question: Why are my teenage students more accurate in English speaking than writing? 


\subsection{The Potentially Exploitable Pedagogic Activity (PEPA)}

As mentioned in the Literature Review, I have chosen a Potentially Exploitable Pedagogical Activity as an investigative and pedagogic activity to investigate my puzzle through EP. The next step would be to design the most suitable activity for me and my students so as to create space for discussion and better understand my intimate reflections.

The PEPA is designed to integrate the work for understanding into an existing curricular activity (ALLWRIGHT, 2003, p.129). Integration is the key word when developing a PEPA and my purpose was to create harmony between my students and the activity, therefore making them aware of our exercise. Since the school I work at does not follow a specific teaching methodology, creating a space for discussion as a classroom activity would be very welcoming. And, lastly, figure out how to unfold a satisfactory PEPA.

It is very important to enable my readers to situate themselves during my analysis and, as described above on the Methodology, the classroom in question is of four students and, for the sake of anonymity, I have designated them John, George, Paul and Ringo. During the PEPA, all of them wore tags to prevent any confusion through the course of the activity.

Like most teachers, I assume, self-observation and self-evaluation are carried out, not only as the very first steps, but by instinct as well. Personally, I cannot even speculate about a classroom where the teacher does not constantly impose questions on him or herself regarding every participant's performance, behavior, and feelings. Therefore, as my own reflection, I have decided to write down my thoughts concerning what I understand to be some of my students' emerging personality trades. Trying to make it more discrete and easily understood, I organized my notes into a table, in which I systematize my perceptions during my class.

\begin{tabular}{|l|l|}
\hline 1.John & $\begin{array}{l}\text { 14-year-old boy, a little bit shy but not } \\
\text { insecure, the quietest student in class }\end{array}$ \\
\hline
\end{tabular}




\begin{tabular}{|l|l|}
\hline 2.George & $\begin{array}{l}\text { however feels comfortable with the } \\
\text { other students. }\end{array}$ \\
\hline 3. Paul & $\begin{array}{l}\text { 13-year-old boy, very chatty with } \\
\text { perfect pronunciation, confident but } \\
\text { humble, an incredibly fast learner and } \\
\text { laughs a lot with friends. }\end{array}$ \\
\hline 4. Ringo & $\begin{array}{l}\text { 14-year-old boy, outgoing and friendly, } \\
\text { very talkative and sociable with other } \\
\text { students, very funny and sarcastic but } \\
\text { less fluent than John and George. }\end{array}$ \\
\hline $\begin{array}{l}\text { 14-year-old boy, very sociable, makes } \\
\text { friends and jokes easily, very } \\
\text { communicative but gets nervous } \\
\text { whenever he makes a mistake on the } \\
\text { spotlight. }\end{array}$ \\
\hline
\end{tabular}

Table 1 - Notes about the students' personalities

After coming up with that behavioral pattern as a preparatory action for my Potentially Exploitable Pedagogical Activities (PEPA), now I could proceed to my next step of fairly thinking and developing the activity itself, regarding my personal experience. Getting to know them better and taking their personalities into consideration would, apparently, make the approach more comprehensive.

My intention is to make my students feel comfortable and challenged simultaneously. Logically, the PEPA would be conducted through speaking and writing, turning details from each and every one's production perceivable.

The first part of my PEPA is a straightforward questionnaire with the intention of making my students aware of their skills, as well as preferences. It consists of ten simple and fast questions:

1) Do you like the English language? 
2) Why do you study it?

3) Which skill do you like to practice the most?

4) Which skill do you like the least?

5) Do you have any contact with English outside the classroom? Explain.

6) Do you study English outside the classroom? If so, where?

7) Do you prefer to speak English or to write it?

8) Do you have the habit of reading and or writing in English?

9) Do you have the habit of speaking and or listening in English?

10) Which skill do you have more contact with outside the classroom?

Having these questions drafted on the board, I have given them some minutes and some paper sheets to answer all of them individually. Subsequently, they had to expand their answer to question 5 into the format of a paragraph. During the exercise, they did not stop talking to each other, however, it was all in English: asking each other questions, making jokes at their own expenses, sharing their opinions, with few mispronounced words. They repeatedly asked me how to spell a word or two but never pronounced these doubtful words incorrectly. It is incredible how, during a writing exercise, most of the students felt the need to share through the channel of sounds.

Once the reflective writing practice was over, it was time to engage in the next step of the PEPA, our own discussion in class. When I mentioned that we were going to do the activity through the speaking mode as well, their reaction was much more positive than before, except for John, who apparently does not react so emotionally to the activities, being the shyest student in the classroom. The speaking activity was performed as a natural discussion about their contact and experiences with English as a second language. Since they were so eager to talk and listen to their colleagues, I wanted to grant them the time and space to do so. Their answers from the questionnaire and the transcript of our recorded group discussion will be presented in the next section of this paper. 
Having completed both PEPAs my next step was conducting an analysis based on the outcomes of the entire process. I will broaden my research from my methodology to my findings in the section to come, Analysis and discussions. 


\section{ANALYSIS AND DISCUSSIONS}

The purpose of the fourth section of this paper is to present my findings and results that have been reached during the investigative process. It is influential to this analysis to report what I could observe since the moment I have embraced my research question until the ending of the PEPAs.

As specified before in a prior section of this paper, the PEPA was a writing activity as well as a speaking one. The first was a questionnaire and, the second, a group discussion, both based on their views and experiences with English acquisition. On the following table, the questions and my students' answers are presented.

\begin{tabular}{|c|c|c|c|}
\hline \multicolumn{4}{|c|}{ 1) Do you like the English language? } \\
\hline John & George & Paul & Ringo \\
\hline Yes, I do. & Yes, I do. & Yes, I do. & Yes. \\
\hline \multicolumn{4}{|c|}{ 2) Why do you study it? } \\
\hline John & George & Paul & Ringo \\
\hline $\begin{array}{l}\text { Because I feel } \\
\text { it'll be important } \\
\text { for my future. }\end{array}$ & $\begin{array}{l}\text { Because it is an } \\
\text { important and } \\
\text { universal language. }\end{array}$ & $\begin{array}{l}\text { Because, today, it is } \\
\text { the universal } \\
\text { language. }\end{array}$ & $\begin{array}{l}\text { Because my parents } \\
\text { said it was } \\
\text { important. }\end{array}$ \\
\hline \multicolumn{4}{|c|}{ 3) Which skill do you like to practice the most? } \\
\hline John & George & Paul & Ringo \\
\hline I prefer reading. & Speaking. & $\begin{array}{l}\text { I like listening and } \\
\text { speaking. }\end{array}$ & $\begin{array}{l}\text { Speaking and } \\
\text { listening. }\end{array}$ \\
\hline \multicolumn{4}{|c|}{ 4) Which skill do you like the least? } \\
\hline John & George & Paul & Ringo \\
\hline
\end{tabular}




\begin{tabular}{|l|l|l|l|}
\hline $\begin{array}{l}\text { I like speaking the } \\
\text { least. }\end{array}$ & Writing. & Reading. & $\begin{array}{l}\text { Writing, for sure and } \\
\text { then reading. }\end{array}$ \\
\hline
\end{tabular}

5) Do you have any contact with English outside the classroom?

\begin{tabular}{|c|c|c|c|}
\hline John & George & Paul & Ringo \\
\hline $\begin{array}{l}\text { Yes, I do. I use } \\
\text { Reddit, a social } \\
\text { media with a lot } \\
\text { of communities. }\end{array}$ & $\begin{array}{l}\text { Yes, videos on } \\
\text { YouTube, series on } \\
\text { Netflix and } \\
\text { videogames. }\end{array}$ & $\begin{array}{l}\text { Yes, watching } \\
\text { YouTube videos, } \\
\text { TV series, movies } \\
\text { and playing } \\
\text { videogames. }\end{array}$ & $\begin{array}{l}\text { Yes, I watch a lot of } \\
\text { movies and series. I } \\
\text { like YouTube videos } \\
\text { too. }\end{array}$ \\
\hline
\end{tabular}

6) Do you study English outside the classroom? If so, where?

\begin{tabular}{|l|l|l|c|}
\hline \multicolumn{1}{|c|}{ John } & \multicolumn{1}{|c|}{ George } & Paul & Ringo \\
\hline $\begin{array}{l}\text { Yes, I do. I study } \\
\text { at school, but I } \\
\text { feel the teachers } \\
\text { are not very good. }\end{array}$ & $\begin{array}{l}\text { Yes, during English } \\
\text { classes at school. }\end{array}$ & Yes, just at school. & At my school. \\
\hline
\end{tabular}

7) Do you prefer to speak English or to write it?

\begin{tabular}{|l|l|l|l|}
\hline \multicolumn{1}{|c|}{ John } & \multicolumn{1}{|c|}{ George } & \multicolumn{1}{c|}{ Paul } & \multicolumn{1}{c|}{ Ringo } \\
\hline I prefer to write it. & Speaking. & I prefer to speak. & Speak. \\
\hline
\end{tabular}

8) Do you have the habit of reading and or writing in English?

\begin{tabular}{|l|l|l|l|}
\hline John & George & Paul & Ringo \\
\hline
\end{tabular}




\begin{tabular}{|l|l|l|l|}
\hline $\begin{array}{l}\text { I have the habit of } \\
\text { reading, but I } \\
\text { don't write much. }\end{array}$ & $\begin{array}{l}\text { I don't read that } \\
\text { much, but my } \\
\text { videogames are in } \\
\text { English. And I never } \\
\text { write in English. }\end{array}$ & $\begin{array}{l}\text { Rarely. I listen to } \\
\text { English more than I } \\
\text { write or read. }\end{array}$ & $\begin{array}{l}\text { Not much, but } \\
\text { reading more than } \\
\text { writing. }\end{array}$ \\
\hline \multicolumn{1}{|c|}{ 9) Dohn } & \multicolumn{1}{|c|}{ George } & Paul & Ringo \\
\hline Yes, I do. & $\begin{array}{l}\text { Yes, specially } \\
\text { listening. }\end{array}$ & Yes. & Yes. \\
\hline $\begin{array}{l}\text { 10) Which skill do you have more contact with outside the classroom? } \\
\text { John } \\
\text { reading. }\end{array}$ & $\begin{array}{l}\text { Listening, for sure. } \\
\text { I have more }\end{array}$ & $\begin{array}{l}\text { Listening, but I also } \\
\text { read sometimes. }\end{array}$ & Listening. \\
\hline
\end{tabular}

Table 2 - Students' answers to the questionnaire.

After having thoroughly answered the questionnaire, my students were handed another paper sheet into which they could expand their answers to question 5 (Do you have any contact with English outside the classroom? Explain.). The purpose of this question was to make them think about how they have been influenced by their first foreign language. This explanation would also be done in writing, generating an opportunity for me to pay attention to any spelling inaccuracy. Bellow, we are able to read the students' answer to question number 5, altogether with their spelling mistakes in italic.

- John:

I prefer to read in English because I feel that it is easier to understand. I used to read some interactive games from a company named 'Choice Up Games' and they're entirely in English. Now, I mostly use Reddit, a social media with a lot of virtual groups. 
- George:

I usualy watch a lot of videos and series online. I do play video games too. Everything that I sad has one thing in comon, everything is in English and that's good for me because I practice a lot at home.

- Paul:

When I'm watching videos on YouTube and films with subtittles in Portugues and sometimes without subtittles, and when I'm playing video games and speaking with other players and reading rules of the games.

- Ringo:

I watch YouTube videos in inglish, whith out subtittles and movies and series whith subtittles in Portuguese and sometime in inglish.

After having skimmed their answers for key words, I have encountered spelling mistakes in words which I knew they were familiar with the meaning and pronunciation. However, I thought about how they could mouth these words perfectly and yet not be adept to spell them correctly. The entire purpose of this section is to seek understanding through an analysis based on the expansion of my research question. When reading thoroughly my students' answers, I could notice that favoring listening as a skill was an aspect in common to most of them.

Based on the questionnaire and the debate amongst the students, it is very clear that most of them relate better to the skills of speaking and listening. First of all, as I have mentioned before, their reaction towards a speaking assignment was more positive than the writing one due to a feeling of comfort and ease. Second of all, most questions from the questionnaire are related to language skills and it is possible to notice that most students prefer to speak and listen rather than read and write.

For the second segment of the PEPA, I brought all these ideas and thoughts from the questionnaire into a light group discussion and its entire transcript can be found in the Annex section at the end of this paper. Next, the readers will be able 
to observe some selected excerpts from the talk held in class which are relevant to the analysis and discussion of my research question, based on my theoretical background.

- Excerpt 1:

Luiza: Yes. Do you prefer to speak or to write in English?

John: I prefer to write.

At the beginning of our class discussion, I could confirm that John's preferable way of expressing himself is writing over speaking, which makes sense considering his introverted personality displayed during class activities. Furthermore, he was the only one who did not make any spelling mistakes on the writing assignment. It is noticeable in John's answer to the questionnaire that his favorite language skill is reading, which could possibly be an explanation for this precision whilst writing a paragraph in English, since he meticulously observes more words in written English than his classmates. When a learner participates in a linguistic event, direct and indirect affordances become available depending on the abilities and aspirations of the learner (VAN LIER, 2004, p.90).

- Excerpt 2:

Luiza: Do you prefer to write or to speak in English?

George: To speak in English.

Luiza: And what about you, Paul?

Paul: To speak.

Luiza: To speak. Ok. And what about you?

Ringo: Speaking.

Concerning the other students, all of them favored speaking over writing. Surely, George, Paul and Ringo are more outgoing and sociable, making it sensible for them to somehow feel more comfortable than John. However, we must infer the fact that all of them, except for John, made spelling mistakes during question 5 (Do you have any contact with English outside the classroom? Explain.). Thus, besides their personal behavioral, I could already understand that John feels more at ease when writing due to his preference in reading. Now, it was time to understand the inclination towards speaking from most of the group. 
- Excerpt 3:

Luiza: Why do you prefer to write in English?

John: I feel like it's more accurate.

Luiza: More accurate? Ok, very good. And what about you guys, the rest of you? Why do you prefer to speak in English?

George: Because, to me, I don't know why, it's easier.

Ringo: Yeah, it's easier.

Luiza: You find it easier. But why do you think you it's easier?

Ringo: Because the spelling is difficult. Like, which letter you have to use to complete a word.

Paul: Oh yeah!

Luiza: Ok.

Paul: Which letter you must double or not.

According to the third excerpt extracted from the PEPA, John felt writing provides more accuracy, while George, Paul and Ringo all agreed that speaking is easier. In George's words, “Because, to me, I don't know why, it's easier." These students' understandings seem to echo van Lier's belief that learning includes both direct and indirect perception and perception of self as well as of the other, including the environment (VAN LIER, 2004, p.89). Based on what Van Lier believed to be an approach to learning a foreign language, the world is filled with learning opportunities and it is incredible how language learners can acquire knowledge beyond the four walls of a classroom and sometimes, not even notice it.

As explained in the Literature Review section of this paper, Language Ecology claims that the environments, whatever they may be, provide different tools for Second Language Acquisition (SLA) to happen. The ability to use language to communicate with others, by contrast with merely learning rules, is acquired through being exposed to comprehensible input as well as in and through interaction with others (KRAMSCH, 2008, p.20). In addition to the classroom, there are other situational contexts in which they have found themselves in constant influence of the English language and, somehow, enhance their knowledge. John, for example, has a stronger encounter with written words for he likes to read in 
English, which makes it plausible for him to make no mistakes in the writing assignment.

- Excerpt 4:

Luiza: Ok. Ok. Very good. And at school, in your English classes, do you practice more speaking or more writing?

All students: Writing.

Luiza: You practice more writing.

George: Actually, kind of both.

As we note on the excerpt above, all of my students practice more writing at school, however, only one of them managed to write a paragraph with absolutely no spelling mistakes. The school is one of their ecosystems, becoming a space to learn English, but, of course, there are many others where they can find more comfort and self-encouragement. The language does not act alone in the meaningmaking process (VAN LIER, 2008, p. 599). I believe a teenager when occupying oneself with recreational activities, alongside possible knowledge, it comes more naturally for some of them.

\section{Excerpt 5:}

Luiza: You listen to it a lot. How? How do you listen to English?

George: I usually watch videos on YouTube in English.

Luiza: Ok.

George: Series and movies that are usually in English, with subtitles, but they are speaking English.

Luiza: Ok.

George: And sometimes, Ted Talks, when I have nothing else to do.

The language classroom is not an island unto itself (VAN LIER, 2008, p. 600 ). On expert 5 , we notice how George finds himself constantly in contact with the sound of words in English while watching many series, movies and videos in English, including when boredom strikes. This regular activity of his gave him space to grow as a listener and, consequently, as a speaker as well. The nature of language itself must also be seen to involve not just words and syntax, but also all other sources of meaning making that are available in the environment (VAN LIER, 
2008, p.598). In George's cases, these found sources of meaning making are YouTube videos, series, movies and TED talks.

Excerpt 6:

Luiza: So, when you usually watch your series and movies, are the subtitles in English or Portuguese?

George: Usually in Portuguese. But, sometimes, I put it in English.

Furthermore, George also finds himself reading subtitles in Portuguese more often than in English. This student is clearly more familiar with sounds, due to many options of video watching, rather than English written words.

\section{Excerpt 7:}

Luiza: What about you, Paul? Do you listen to English a lot outside of the classroom?

Paul: Yeah. Like, the same as George.

Luiza: Very good. And what about you Ringo?

Ringo: The same as the others.

Luiza: The same? Ok. So, you guys have the habit of watching a lot of things?

Paul and Ringo: Definitely.

George: Sure.

John: Yes.

In this group, when engaging in leisure activities, they opt for televised ones. George, Paul and Ringo are all interested in YouTube videos, series, movies and even video games when relaxing after a long week. Most of the contents of their concern are to be found in the English language. They have a great deal of influence of the sound of words in English from different monologues and dialogues from movies series, videos and video games. Ecological theories of learning are prompting us to seriously conceptualize the relationship of individuals and their objects and artifacts, in particular computer technology (KRAMSCH, 2008 , p. 24). In addition to that fact, it is perceived from their answers and utterances that when observing written words, they are in the format of subtitles in Portuguese, making it less probable to fully grasp the spelling of the word in 
English. George is also capable of impersonating different accents in English. He is capable of watching movies and series in English but with characters from all over the world.

\section{Excerpt 8:}

Paul: Sometimes, I try not to put on the subtitles.

Luiza: At all? No subtitles at all?

Paul: Yeah!

Ringo: Me too!

In addition to that fact, Paul and Ringo, whose least favorite skills are reading and writing, sometimes challenge themselves by watching whatever they please with no subtitles at all, making them closer and more attentive to pronunciation rather than spelling.

\section{Excerpt 9:}

Luiza: Ok. Great! So, what do you think is the easiest part in English?

To understand something, to speak, to write or to read? The easiest.

George and Paul: To understand.

John: To read.

Ringo: It depends on the ... on the...'naturality'?

Luiza: What?

Ringo: The place where the people ... that they...

Luiza: The nationality?

Ringo: Yes!

As mentioned earlier, according to Leo Van Lier, an ecological perspective on language learning sees language as part of larger meaning-making resources that include the body, cultural-historical artifacts, the physical surroundings, in short, all the affordances that the physical, social, and symbolic worlds have to offer" (VAN LIER, 2008, p.599). The way they react to the language skills is very much related to where they are and the affordances their surroundings can provide. John thinks reading is easier, however, George and Paul clearly believe understanding is less complicated and Ringo grasps whichever inflection he is more accustomed to listen to. Therefore, John's environment provides more tools towards reading and 
writing, while George, Paul and Ringo's provide more tools towards listening and speaking and all of that is reflected in their common environment, our classroom. All elements within an ecosystem (such as a classroom) are interrelated (VAN LIER, 2010, p.5).

\section{Excerpt 10:}

Luiza: Very good, George! But how did you get that Russian accent? I mean, how do you know that this is the Russian accent?

George: I watched a series...

Paul: Which one?

George: Orange is the new black.

Luiza: Ok.

George: There is a Russian character.

Luiza: Oh, yes! Red.

George: Yes, her name is Red! And she has a Russian accent and I thought it was very thick and funny. And then I searched videos on Internet of people speaking in Russian. And I started to watch them speak so I could make an impression!

Luiza: Ok. Very nice!

Ringo: And Alabama accent!

Luiza: And Alabama too!

George [in 'Alabama' accent]: Alabama people get to speak like that.

In the extract above, we can perceive how George can act on impressions of different accents, from Russian to an Alabama one. During this moment of the debate, I was astounded to see how a young boy could already relate in a different level of speaking in a foreign language. Not only is he speaking a second language, he is imitating different accents and actually being aware of different inflections of the English language. He only had heard it, while watching a series in the comfort of his home and, in little time, he became knowledgeable about how Russians normally speak English. I might be expected to participate in a conversation but remain silent, that is also movement (VAN LIER, 2010, p.4).

\section{Excerpt 11:}

Luiza: Do you have the habit of looking for the lyrics? 
John: Yeah, I try to understand them while I'm listening to them.

According to the last analytical passage from the PEPA, I noticed that, even when involving in activities that require more of his listening skills, John finds himself interested in a deeper understanding of the lyrics. Whether it is to feel more intimate with the song or to fully understand its meaning, it makes him read and, therefore, master more words and their orthography.

The purpose of my PEPA is to learn the students' affordances offered by their daily lives. By doing that, I try to better discern their difficulties from their advantages. When comprehending their obstacles and, as well as what they can do effortlessly, the path down to 'quality of life', as developed in EP, turns brighter. 


\section{FINAL CONSIDERATIONS}

The purpose of this paper is to contribute somehow through my first experience as a researcher. As I have mentioned in the introduction section of this study, we, as teachers, puzzle ourselves constantly when facing different classes, tasks and students. Questions come to mind and many times, instead of answers, we reach understandings.

Having decided on my research question, I went after a theoretical framework that could help me research my question. Why are my teenage students more accurate in English speaking than writing?

As a student, I came across the idea of Language Ecology, a subcategory of Educational Linguistics that expands the idea of learning as a process that involves acquiring second language knowledge through what the situational and social context can provide. It believes that a person can uptake within knowledge and enhance language skills and sometimes not even be aware of the process.

Based on my classes and readings as a post-graduation student, I found the theoretical framework within which I would like to develop my question. My next step would be how to conduct this study. Since Language Ecology provides an idea of interaction as part of the learning process, I have decided to choose EP as an investigating framework. EP focus on understanding rather than solving it and my focus was exactly to understand beyond my students' behavior and performance inside the classroom.

As for my experience concerning this work, I started questioning myself how this puzzle, these students and my study have affected me, in any way possible. Therefore, I had another question and, now I believe how natural it is. I suppose questioning ourselves makes us evolve, even if it does not lead you to a resolution.

Regarding this thought, it revealed that this paper has sharpened my critical side, professionally speaking. It made me want to be more assertive and insistent when facing doubts and hesitation at work, especially when this skepticism is purely in my mind. However, it has softened me personally and it was necessary, since I, as a human being, demand too much of myself. It is beyond reason not to have all the answers for all the questioning in life. 
Besides my way of living and working, this paper has also revealed the capacity of independent thinking from young learners. They are perfectly capable of self-teaching and even learning without noticing it. It is very important not to underestimate the potential of children and teenagers for we have once filled their shoes.

Finally, after concluding this work with pride, I have to say that I hope that my thoughts and ideas can, in a way or another, be useful for other professionals because I know that they also have their own puzzles. 


\section{REFERENCES}

ALLWRIGHT, D.; HANKS, J. The developing language learner: An introduction to Exploratory Practice. Basingstoke, UK: Palgrave Macmillan, 2009.

EGERTON, F. Greeks and Romans: Antiquity. In: Roots of Ecology: Antiquity to Haeckel (pp. 1-16). Berkeley: University of California Press, 2001.

HAECKEL, E. Life. In: The Wonders of Life: a Popular Study of Biological Philosophy. New York: Harper and Brothers Publishers, 1905.

HANKS, J. Developing Language Teachers with Exploratory Practice. London, UK: Palgrave Macmillan, 2018.

Exploratory Practice in Language Teaching. London, UK: Palgrave Macmillan, 2017.

KRAMSCH, C. Ecological Perspectives on Foreign Language Education. In: Language Acquisition and Language Socialization, Volume 41, Issue 3, (pp. 389408). Cambridge: Cambridge University Press, 2007.

From Practice to Theory and Back Again. In: Language, Culture and Curriculum. California, 2002.

KRESS, G. Multimodality. In: Multiliteracies: Literacy Learning and the Design of Social Futures. London and New York: Routledge, 2000.

LIER, V. All Hooked Up: An Ecological Look at Computers in the Classroom. (pp. 281 - 301). Washington D.C, 1998.

Ecological-Semiotic Perspectives on Educational Linguistics. In: The Handbook of Educational Linguistics. Oxford, UK: Blackwell Publishing, 2008.

. The Ecology of Language Learning: Practice to Theory, Theory to Practice. In: Social and Behavioral Sciences, Volume 3 (pp. 2-6). Monterey: Blackwell Publishing, 2008.

The Semiotics and Ecology of Language Learning. In: Utbildning \& Demokrati, Volume 13, Issue 3 (pp. 281-301). Kluwer Academic Publishers, 2004.

LINCOLN, Y.; GUBA, E. Paradigmatic controversies, contradictions, and emerging confluences. In: SAGE Handbook of Qualitative Research. California: SAGE, 2010 


\section{ANNEXES}

Teacher: Ok, guys, let's move on with our activity. Now it's time for us to talk with each other. So, tell me something, John...

John: Me, yes. What?

Teacher: Yes. Do you prefer to speak or to write in English?

John: I prefer to write.

Teacher: To write? What about you, George?

George: I prefer.... hum... wait, what?

Teacher: Do you prefer to write or to speak in English?

George: To speak in English.

Teacher: And what about you, Paul?

Paul: To speak.

Teacher: To speak. Ok. And what about you?

Ringo: Speaking.

Teacher: Speaking? Ok, so three of you prefer to speak in English rather than read or write in English. John, why do you like to write in English?

John: Well, I...

Teacher (me): Why do you prefer to write in English?

John: I feel like it's more accurate.

Teacher (me): More accurate? Ok, very good. And what about you guys, the rest of you? Why do you prefer to speak in English?

George: Because, to me, I don't know why, it's easier. 
Ringo: Yeah, it's easier.

Teacher (me): You find it easier. But why do you think you it's easier?

Ringo: Because the spelling is difficult. Like, which letter you have to use to complete a word.

Paul: Oh yeah!

Teacher (me): Ok.

Paul: Which letter you must double or not.

Ringo: Yes!

Teacher (me): Ok. Ok. Very good. And at school, in your English classes, do you practice more speaking or more writing?

All students: Writing.

Teacher (me): You practice more writing.

George: Actually, kind of both.

Teacher (me): Kind of both, ok. And what about outside our classes and outside of school? What do you have more contact with?

Ringo: Definitely not writing.

George: hmmm...I don’t speak a lot.

Teacher (me): You don't, George?

George: Outside of school or...?

Teacher (me): Yes, and outside our classes.

George: Oh, yeah, I don't speak a lot but I do listen to it a lot.

Teacher (me): You do what, sorry?

George: I listen to it a lot. 
Teacher (me): You listen to it a lot. How? How do you listen to English?

George: I usually watch videos on YouTube in English.

Teacher (me): Ok.

George: Series and movies that are usually in English, with subtitles, but they are speaking English.

Teacher (me): Ok.

George: And sometimes, Ted Talks, when I have nothing else to do.

Teacher (me): So, when you usually watch your series and movies, are the subtitles in English or Portuguese?

George: Usually in Portuguese. But, sometimes, I put it in English.

Teacher (me): Ok. So, you can practice a little bit.

George: Yes.

Teacher (me): What about you, Paul? Do you listen to English a lot outside of the classroom?

Paul: Yeah. Like, the same as George.

Teacher (me): Very good. And what about you Ringo?

Ringo: The same as the others.

Teacher: The same? Ok. So, you guys have the habit of watching a lot of things?

Paul and Ringo: Definitely.

George: Sure.

John: Yes.

Teacher: YouTube? Netflix? 
Ringo: Rick and Morty.

Teacher (me): Series? Movies? Sorry?

Ringo: Rick and Morty.

Teacher: Oh, Rick and Morty! I love Rick and Morty! It's amazing! So when you...

Paul: Sometimes....

Teacher (me): Ok, tell me, Paul.

Paul: Sometimes, I try not to put on the subtitles.

Teacher: At all? No subtitles at all?

Paul: Yeah!

Ringo: Me too!

Teacher (me): That's really good! So you get to practice a lot of your listening skills.

Paul: Yes.

Teacher (me): Ok. Great! So, what do you think is the easiest part in English? To understand something, to speak, to write or to read? The easiest.

George and Paul: To understand.

John: To read.

Ringo: It depends on the ... on the...'naturality'?

Teacher (me): What?

Ringo: The place where the people ... that they...

Teacher (me): The nationality?

Ringo: Yes! 
Teacher (me): Ok. Perfect.

Ringo: If the person is from the United States or somewhere else.

Teacher (me): Ok. It depends on the accent.

Paul and Ringo: Yes!

Teacher (me): Ok, I get it. And can you distinguish different accents?

George and Ringo: Yeah!

John: Humm...most times.

Teacher (me): Like, for example, George can do a perfect Russian accent.

Paul: Yeah!

Ringo: Yeah, go, George!

Paul: You can do it!

George [in Russian accent]: I can't do it right now.

Paul: You need to drink vodka!

George [in Russian accent]: I need to drink vodka before so I can make it better!

\section{[All students laugh]}

Teacher (me): Very good, George! But how did you get that Russian accent? I mean, how do you know that this is the Russian accent?

George: I watched a series...

Paul: Which one?

George: Orange is the new black.

Teacher (me): Ok. 
George: There is a Russian character.

Teacher (me): Oh, yes! Red.

George: Yes, her name is Red! And she has a Russian accent and I thought it was very thick and funny. And then I searched videos on Internet of people speaking in Russian. And I started to watch them speak so I could make an impression!

Teacher (me): Ok. Very nice!

Ringo: And Alabama accent!

Teacher (me): And Alabama too!

George [in Alabama accent]: Alabama people get to speak like that.

[All students laugh]

George [in Alabama accent]: Last season, I was playing a game we call, GTA, I don't know how to say that in any other accent!

Ringo [in Alabama accent]: I gotta a gun!

Teacher (me): That's a good accent. And you, John?

John: Yes.

Teacher (me): You said that you prefer to write and to read, instead of listening and speaking

John: Yes!

Teacher (me): But do you have the habit of listening and speaking as well?

John: Yes, I also speak alone, I mean, by myself and I listen to a lot of music.

Teacher (me): Usually in English? Like, American songs, English songs...

John: Yes, usually American. 
Teacher (me): How often do you listen to music?

John: Hum... Music? Almost every day.

Teacher (me): Do you have the habit of looking for the lyrics?

John: Yeah, I try to understand them while I'm listening to them.

Teacher: Ok, perfect, very good. Ok, guys! Excellent work! 